\title{
米国の学部学生の負担が増大
}

\section{US students pay for downturn}

EMma MARRIS 2010 年 6 月 10 日号 Vol. 465 (678-679)

www.nature.com/news/2010/100609/full/465678a.html

\section{世界の大学は経済不況によって試練に直面している。米国の公立大学の資金難は、 授業料値上げによっても解消されず、学生は、苦境を実感している。}

米国公立大学協会 (APLU ; ワシントン D.C.) によれば、米国の学部学生 1700 万人の約 4 分の 3 が州立大学に通って いる。その州立大学が今、世界不況に よって痛手をこうむっている。経済危機 が襲った 2008 年秋、多くの州政府は、 直ちに予算カットに踏み切った。そして 2009 年の予算では、さらに痛みが増し た。2009 年晚夏に APLU の会員大学の うちの 87 大学を対象に実施されたアン ケート調査では、州からの補助金が削減 されたと回答した大学が 85 パーセント を占め、授業料值上げと入学者定員増に もかかわらず財源が減少したと回答した 大学が 50 パーセントに上った。

また、予算カットの結果、学部学生の 教育に影響が出ていることを半数以上の 大学が認めている。1 クラス当たりの学 生数は数百人規模に膨れ上がり、教育助 手の人数が減り、体感型学習のできる実 験室や一部の講座が丸ごと消滅し、数々 の課程や学部学科が廃止された。これか らも事態は悪化を続けると予想されてい る。景気回復の足取りは鈍く、州政府の 税収回復は、景気回復の後になるのが必 然だからだ。一方、2009 年に議会で承 認された連邦政府の景気刺激策は、この 秋には底をつくことになっている。

「ほとんどの学部学生にとっては、こ れまでより大きな教室での講義となり、 実験時間が減り、図書館の利用可能時間 も減ることになるでしょう。希望する講 座に入れない学生すら出てきます」。こ う話すのは、APLU 副会長（学務担当）
の David Shulenburger だ。

特に、講座の人気が高まっているにも かかわらず、学部の予算が減少している 大学では、多くの理学系学部学生が、苦 境を体感している。

理学系学部学生の予算は近年になく 逼迫した状況にあるが、その一方で、生 命科学系の講義を受ける学生が急増して いる、とカリフォルニア大学バークレー 校の Cathy Koshland 副学長(受講計画・ 施設担当）はいう。こうした学生は、米 国での高齢化による医療関連の雇用の増 加予測とバイオテクノロジー、バイオエ ネルギー、バイオ医薬品の台頭に引き寄 せられている。「今ホットな研究分野に は、生物学的要素が色濃くみられます」 と Koshland は話す。

影響を受けるのは、生物学系の学科に とどまらない、と Koshland は続ける。 「学生は、生物学の講義を受ける前に、 ある程度の数学と化学の知識を身に着け ていることが求められます」。そのため、 こうした科目の教室でも過密状態が深刻 化している。これがドミノ効果を生み出 し、何年にもわたつて大学の教育プログ ラムに影響を与えることがある。こうし た過密化に対処するため、カリフォルニ ア大学バークレー校の各学部では、討論 型講義の頻度を減らすか、クラスの大き さを 2 倍にした。また、場合によっては、 講義と実験を切り離し、同じ学期中にそ の両方を取らなくてもよくなった。

これと似た財源の縮小とクラスの過密 化は、全国的にみられる。ワシントン大
学 (シアトル) では、生物学の初級課程 の学生数が 700 人に増えたため、化学 の初級課程で、実験の半分を中止せざる を得なくなった。カレッジ・オブ・サザ ンネバダ (ネバダ州ラスベガス) では、 24 時間体制で講座を増設し、深夜の講 座も開設した。

教育内容が低下する一方で、大学の授 業料は值上がりしている。ミズーリ科学 技術大学（ローラ）では、1 クラスの人 数が増える一方で、授業料の值上げが行 われ、多くの公立大学が不況以前から 行っていたように、民間からの寄付金で 州からの補助金の目減り分を補おうとし ている。同大学の学長 John Carney は、 こう話す。「時代がよかったころは、運 営予算の約 60 パーセントを州からの補 助金で賄っていましたが、それが今では 約 27 パーセントに落ち込んでいます。 質の高い大学教育プログラムを組むに は、手品のトリックではなく、収入が必 要なのです」。

米国の公立大学の授業料は、1999 年 以降、毎年、インフレ率プラス約 5 パー セントの值上げが行われてきている（米 国カレッジ・ボードによる)。米国の 4 年制公立大学に通う同一州内に居住する 学生の年間授業料の平均額は 2009 年度 には 7020 ドル（約 60 万円）に達し、 学生とその親や大学助成プログラムを圧 迫している。学生金融支援担当者全国協 会の広報担当 Haley Chitty は、こう話 す。「財政的援助の需要は大幅に増え、

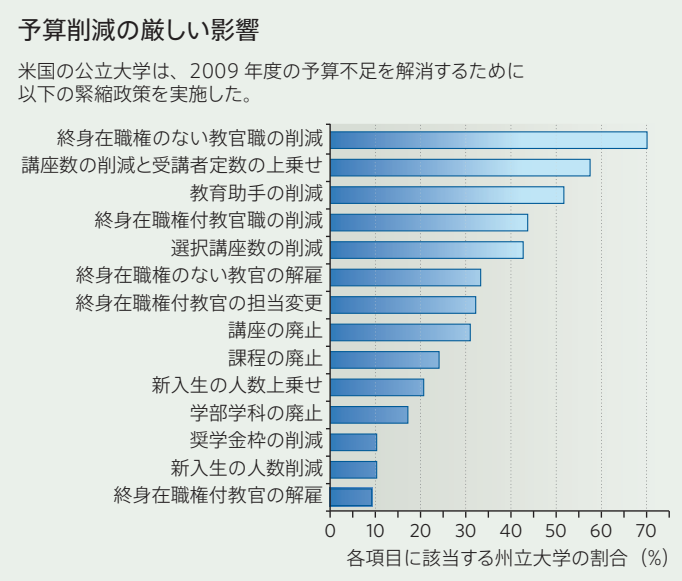


学費援助の資格を有する学生の数も急増

しました」。

連邦ペル給付奨学金は、有資格者全員 に対する助成をうたっているため、この 助成金に対する連邦政府の支出が「爆発 的に増加した」とChitty は話す。しか し大学側としては、授業料値上げと学生 を通じてペル給付奨学金を奪い取ること
だけでは、予算にあいた穴をふさぎきれ ない。2010 年度のペル給付奨学金の最 高額は 5550 ドル（約 47 万円）だ。

不沉によって学部学生の教育にはスト レスと費用が多くかかるようになった が、ほとんどの大学管理者は、学士号は 今でも「お值打ち品」だと主張してい る。「我が校の卒業生は年収 5 万〜 7 万
ドル（約 $430 ～ 600$ 万円）を得ていま すから、現在の授業料について弁解する つもりはありません」と Carney は語る。 Shulenburgerも同じ意見で、「これは たいへんなお買い得品です。長期的にみ れば、学士号の取得より優れた投資はあ りません」と話している。

(翻訳 : 菊川要、要約 : 編集部) 